\title{
ACONTECIMENTO EM AUTORAS NEGRAS E/OU NORDESTINAS
}

\section{Ivânia Nunes Machado Rocha*}

(iD) https://orcid.org/0000-0003-4797-1771

\section{Emanuela Oliveira Carvalho Dourado**}

(iD) https://orcid.org/0000-0002-4083-235X

Como citar este artigo: ROCHA, I. N. M.; DOURADO, E. O. C. Acontecimento em autoras negras e/ou nordestinas. Todas as Letras - Revista de Lingua e Literatura, São Paulo, v. 22, n. 3, p. 1-16, set./dez. 2020. DOI 10.5935/1980-6914/eLETDO 2013915

Submissão: agosto de 2020. Aceite: setembro de 2020.

Resumo: Discutimos a noção de acontecimento (Deleuze) em obras de escritoras negras e/ou nordestinas, objetivando evidenciar perceptos e afetos, considerando devires e desconstrução. Analisamos obras literárias de Conceição Evaristo, Lívia Natália e Jarid Arraes. Para tanto, movimentamos autores como Deleuze e Guattari, Zizek, Nietzsche e outros que dialogam com a nossa proposta. Assim, as obras remetem às possibilidades da literatura enquanto acontecimento, que está em constante transformação.

Palavras-chave: Literatura. Acontecimento. Escritoras negras. Escritoras nordestinas. Deleuze. 


\section{ACONTECER ACONTECENDO}

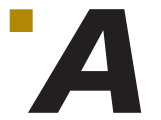

partir da leitura de leitores de Deleuze e Guattari, discute-se a noção de acontecimento e sua relação com a literatura produzida por intelectuais negras e/ou nordestinas. Estudiosos como Zizek; Zourabichvili; Rojas, Serrano e Silva; Bezerra; Levy; Nietzsche e outros são chamados neste texto para dialogar sobre os afetos e perceptos da literatura escolhida, considerando que essa maneira de criar é um "filosofar" da arte.

Em Mil platôs, Deleuze e Guattari (2013) consideram que filosofia e literatura não têm fronteiras, elas são dissolvidas em ato, como possibilidade de simplesmente escrever, numa autonomia e interação entre esses e outros campos da criação. Para Deleuze, o grande problema artístico não é o de representar o visível, mas tornar visivel o invisível. Nesse sentido, não se esgota o acontecimento, uma vez que ele é virtual, imaterial. Não como oposição ao real, mas na arte e na literatura, como na arte se pode experimentar o virtual no real, ou o real nessa virtualidade, como atualização que nunca se separa nesse plano de imanência, numa temporalidade simultânea: passado, presente e futuro. Imagens de pensamentos apenas virtuais e imagens de pensamentos virtuais já atualizados. Há no presente um encontro imediato com o próprio passado e também com o futuro. Numa temporalidade distinta do passado e do que será o futuro. A arte lida com o tempo em seu estado puro.

Contudo, fatos não são acontecimentos, como concebem Deleuze e Guattari em várias de suas obras. Fatos ocorrem de modo transitório e com uma certa duração. Acontecimento, diversamente, não tem duração, mas desdobramentos infinitos. O acontecimento é um fato que continua acontecendo e cujas consequências perduram indefinidamente, ou seja, acontece acontecendo, assim, num gerúndio infinito e constante.

Um acontecimento nunca é singular - é sempre outros, uma vez que as coisas e fatos estão em constante devir. Uma aula, por exemplo, nunca é a mesma para todos - é um devir aula, já que se trata de existência, nunca a coisa em si, a materialidade, mas o que advém dela, sempre diverso e sempre plural e em movimento constante.

Acontecimentos estão na categoria de objetos e/ou ideias que provocam afetos e perceptos que, por sua vez, se propagam em uma cadeia de novos acontecimentos que estão sempre acontecendo, sempre gerando afecções e percepções, num constante devir. É importante salientar que o acontecimento não se reduz ao cotidiano, pois há um estado transcendental, no sentido de continuação, de projeção para além da sua superfície. A Filosofia da Diferença, chamada por Deleuze de Empirismo Transcendental, remove a lógica da transcendência (e faz alusão ao transcendental), uma vez que privilegia a mobilidade perpétua do real, exercida num plano de imanência, recriada a cada vez por meio da experimentação da (re)escrita quando se lê ou produz literatura.

Uma característica básica de um acontecimento é o surgimento surpreendente de algo novo que destrói as certezas, que desmancha as estruturas e/ou esquemas estáveis: um evento traumático é sempre um acontecimento, pois gera, no indivíduo, perceptos e afetos novos, inesperados, tirando-o da trilha que pensava seguir, levando-o a perceber a si mesmo e ao mundo à sua volta de maneira diversa, provocando uma cadeia de reações que, por sua vez, movimentam outras ações e reações, de modo que a pessoa afetada nunca mais será a 
mesma, mas sempre outra(s), já que as coisas passam a ser enxergadas a partir de diversas perspectivas e em constante movimento, em um eterno devir.

Para Slavoj Zizek (2017, p. 8), acontecimento é "algo chocante, fora do normal, que parece acontecer subitamente e que interrompe o fluxo natural das coisas; algo surge aparentemente a partir do nada, sem causas discerniveis, uma manifestação destituída de algo sólido como alicerce”. Assim, acontecimento não é o mesmo que eventualidade, nem algo que ocorre apenas no campo material - é necessário que o indivíduo seja provocado externamente, mas que essa provocação seja apenas como a ponta de um imenso iceberg que vai se revelando aos poucos, através das camadas de personalidade da pessoa afetada pelo acontecimento, que vai se modificando profundamente, de dentro para fora.

Para que o acontecimento aconteça, é necessário um evento, que pode ser externo ou interno ao individuo: as artes em geral e a literatura, em particular, são artifícios capazes de provocar as afecções e percepções do ser humano, ou, como dizia Antonio Candido (1995), podem humanizar o sujeito. Dessa forma, a literatura é também acontecimento.

Ela invoca um estado de indeterminação, de incerteza, como uma zona indiscernivel de imanência, que turva as fronteiras do mundo inteligivel - dos padrões e dos modelos -, pertencendo ao mundo das percepções e das sensibilidades. Um mundo ziguezagueante repleto de variação e estranheza, que impede um fundamento estável e um conhecimento idealizado de verdade, abalando a fé na interioridade e nos valores transcendentais. O que se tem é o que é: um caos imanente, rompendo a pretensão de controle sobre a multiplicidade, num movimento acontecimental que se permite exteriormente em abertura, para uma travessia da passividade à atividade, da reprodução à tradução, num permanente estado de (re)criação.

\section{LITERATURA E ACONTECIMENTO}

O texto literário promove esse movimento, pois transcende a questão temporal e está em constante mudança aos olhos dos leitores que fazem sua recepção. Além disso, a sua natureza tem o sentido de instantaneidade: não está no passado, nem no futuro, apenas no instante em que é lido, mas que permanece ressoando.

A literatura, assim como a filosofia, não tem quaisquer intenções de mudar o mundo, mas de criar outros mundos possiveis, através da possibilidade de fazer submergir nos indivíduos novas formas de enxergar o universo. Assim, o texto literário se desenrola em vários outros. Paradoxalmente, o diferencial entre literatura e filosofia está justamente onde as duas se entrecruzam - no acontecimento presente em ambas (ROJAS; SERRANO; SILVA, 2017). De formas diferentes, cada uma produz o acontecimento, possibilitando, à sua maneira, novas mudanças na vida das pessoas; oportunizando a criação de novos mundos possiveis, novos seres humanos, novos lugares, que levam à reflexão, à desterritorialização, à resistência. Resistir é sentir-se estrangeiro na sua cultura, exilado, em devir, como nos diz Deleuze, e no estranhamento sentem o que não se pode mais tolerar e necessita ser transmutado. Reportando-nos a Guimarães Rosa (1994, p. 46), em Grande sertão: veredas, “o real não está na saída: ele se dispõe para a gente é no meio da travessia”. 
Para Deleuze e Guattari (2001, p. 8 apud ROJAS; SERRANO; SILVA, 2017, p. 174), "a filosofia é a arte de formar, de inventar, fabricar conceitos", enquanto a arte cria perceptos e afetos, distinguindo-se, assim, daquela. Sendo a literatura uma das formas de arte, é, consequentemente, diferente da filosofia, embora exista uma relação entre ambas. O diferencial está nos modos como o acontecimento é expresso através da linguagem empregada tanto pela literatura quanto pela filosofia.

A literatura se dá no âmbito da linguagem e age sobre os individuos pelo devir, pelo movimento, como transformação, como acontecimento que permite novas possibilidades à vida, ao escritor e ao leitor. No patamar do escritor, o acontecimento em literatura é revelado através do trabalho de criação, já que este transforma a linguagem, abrindo possibilidades para o não pensado e o não dito. Nesse sentido, quem escreve dessa forma é bilingue em sua própria língua - o estilo cria a lingua e os acontecimentos tornam a escrita uma arte.

A literatura, diferentemente dos acontecimentos temporais, não requer material além de si mesma. Ela cria, ordena e desordena corpos e lugares imagináveis. Ela também cria mundos em que os acontecimentos surpreendem, pois vão além da realidade sensorial. Além disso, o real é questionável, pois é visto como uma zona de instabilidade, que permanece em constante devir ou em fluxo contínuo, ou seja: a vida não para. Nesse sentido, uma análise da literatura como experiência exige transitar na superficie, o que Blanchot denominou o fora, que estaria ligado ao mundo da imaginação, da criação. A palavra literária produz o outro do mundo. Ela se liga a esse outro como o imaginário se liga ao real (LEVY, 2011).

O acontecimento em literatura se dá por meio de relações virtuais, não no sentido tecnológico, mas no sentido de imaterial, incorpóreo. Dessa forma, o impossivel é possivel como oposição ao possível. Ademais, o sentido da obra literária não pode ser confundido com o seu sentido literal ou figurado, mas com as atribuições de sentidos novos e diversos de leitores. Enquanto linguagem de ficção, pois é sempre uma invenção, diferentemente de uma linguagem corriqueira, ela realiza a si própria. Nesse sentido, ela não é um simples instrumento subordinada a fins práticos de comunicação. Nela as palavras são signos, não uma linguagem que se refere a um mundo prático e exterior; contrariamente, ela vem de um esforço de expressar o que sabemos para se regozijar no que não se sabe. Ela cria mundos, imagens, coisas, transpondo a irrealidade a uma realidade da linguagem. A

[...] ficção aparece como o inabitual, o insólito, o que não tem relação com este mundo nem com este tempo - o outro de todos os mundos, que é sempre distinto do mundo. Mas ao mesmo tempo em que nos retira do mundo, nele nos coloca novamente (LEVY, 2011, p. 25).

É sempre ele e sua imagem ao mesmo tempo. O imaginário desdobra-se do real, mas não como mera cópia do real. O espaço literário, portanto, é esse duplo do imaginário e do real na mesma temporalidade.

Escrever é se expor a essa outra versão do espaço e do tempo, fazer-se senhor do imaginário, não porque o escritor "disponha do irreal, mas porque coloca à nossa disposição toda a realidade. O imaginário não é uma estranha região situada além do mundo, é o próprio mundo, mas o mundo como um conjunto, como o todo" (LEVY, 2011, p. 25). 
François Zourabichvili (2016) aponta que Deleuze, por influência de Nietzsche, observa a existência de duas forças na natureza: as ativas, de um lado; e as reativas, de outro. As primeiras estão ligadas aos processos de criação e, portanto, ao acontecimento. Já as últimas são excludentes - para se ter algo, é preciso negar o outro, negar a força, enquanto potência do outro, o que constitui uma violência.

A violência vem das potências reativas. A literatura, por outro lado, é considerada por Deleuze uma potência criadora, o que não acontece na filosofia (esta lida com conceitos). A existência, no sentido de Deleuze e Nietzsche, é abissal, levando-se em consideração os processos de criação incessante. Para levar esse abismo adiante, são necessárias força, potência, vontade.

Eis que aí é onde entra a literatura; é onde se encontra a beleza do negócio - a potência criadora oportuniza a criação de outros mundos, de outras realidades. A literatura não se preocupa em recriar a realidade, tampouco em ser meramente descritiva. Se fosse empregada apenas para descrever o real, através de técnicas de composição, seria relegada ao utilitarismo. Assim é que encarna a poiesis, que significa fazer, produzir em grego, ou seja, para a literatura, o que interessa é criar.

A desconstrução é um método de criação, uma metodologia usada para construir um objeto através da linguagem - do trabalho especial com esta, pelo emprego dos signos, que não são neutros, já que signo é sempre ponto de vista, sempre um olhar que direciona, que escolhe, que faz opções. Assim:

O signo é essa instância positiva que não somente remete o pensamento à sua ignorância, mas que o orienta, o conduz consigo, o empenha; o pensamento tem certamente um guia, mas um guia estranho, inapreensivel e fugaz, e que vem sempre do fora. Nem objeto desdobrado na representação, significação clara ou explícita, nem simples nada, tal é o signo ou aquilo que força a pensar (ZOURABICHVILI, 2016, p. 65).

Em Deleuze, não há ligação natural entre o pensamento e a verdade; não depende do pensamento pôr-se a procurar o verdadeiro. $\mathrm{O}$ encontro entre o raciocínio e a verdade é fortuito, contingente e conectado ao signo, que é parcial. Portanto, existe a relação pensamento e inesperado, na qual o "fora" escapa ao domínio da lógica. Assim, a "besteira" não só tem direito a fazer parte do pensamento como é bem-vinda. A besteira não como um engano, mas como o non sense, uma vez que o verdadeiro não é objeto do pensamento, mas o sentido e o valor.

O signo, seguindo essa linha de pensamento deleuziano, é acontecimento que faz a intermediação entre o real e a linguagem, comportando sentidos heterogêneos que, por sua vez, geram novos sentidos que são acontecimentos, devires. Por outro lado, o pensamento só pensa sob pressão do signo. Sem pressão, não há pensamento. Entretanto, a besteira traz uma suavidade ao pensamento, não o pressionando.

Pensar, nesse sentido, é sinônimo de pressão. Já o instinto provoca afetos, desejos, vontades, que são potências, mas a verdade encobre esses sentimentos, já que é movida por interesses. Sendo assim, não há relatividade do verdadeiro, mas a verdade do relativo.

Quanto à obra literária, não há veracidade, mas interpretações possiveis, já que tudo se resume ao signo. Os signos constituem tanto a unidade quanto a 
pluralidade da pesquisa - pessoas, objetos e matérias emitem um conjunto de signos. No entanto, os signos são heterogêneos e exprimem gênero, relações e efeitos sobre intérpretes.

Os signos podem ser mundanos, amorosos, sensiveis e artísticos (Zourabichvili fazendo uma leitura dos signos em Proust). A mundanidade é o meio que emite e concentra uma infinidade de signos em espaços muito reduzidos e em alta velocidade. São signos heterogêneos. Já os signos sensiveis ou da natureza são involuntários e são da ordem das impressões ou qualidades sensiveis. Podem ser observados através de um objeto, um cheiro ou um alimento que remete a uma lembrança passada.

Os signos, assim, são mais que aquilo que representam, já que são a própria narrativa, entremeada de discursos e olhares diversos. Por isso, os signos artísticos, dos quais fazem parte a música, a pintura e a literatura, permitem uma multiplicidade de interpretações/traduções, a partir de perspectivas diferentes, ao mesmo tempo que permitem a criação de personagens, de máscaras. Porquanto, o que interessa numa pesquisa guinada à obra literária é mapear os modos que o povo inventa para ir lá fora, produzindo estratégias, outros/seus percursos, que não são imagens do ideal, mas a criação do que se quer em ato, e as potências que se trazem para a (re)criação.

A literatura, assim, entremeada de signos, traz em si o germe da criação aberta a infinitas possibilidades de outras criações, sempre em movimento, o que é possível observar em obras de intelectuais negras e/ou nordestinas, cujas temáticas abordam questões tais como a violência contra a mulher, mortes, anseios, movimentos circulares, traumas, dores e insights provocados pelo despertar de novos olhares, novas formas de enxergar o mundo, traduzidos em prosa e poesia.

\section{ACONTECIMENTO EM AUTORAS NEGRAS E/OU NORDESTINAS}

Num movimento deleuziano, essa vontade de traduzir as posses e a sensação do vivido/sentido/imaginado, comunicar desígnios, codificando desejos no embate com as forças do fora, dão a pensar.... Codificar é conhecer. E exige a criação de outras imagens que em potência estão lá. Não dadas, mas prenhes de significados. A codificação como estratégia exige a ação de seus traçados. Esse conjunto de códigos é criado pelo uso de signos que explicita usos onde a vida acontece e é desterritorializada, mas nunca como conhecimento verdadeiro, puro, sacralizado. Nesse sentido, codificar é um exercício de perversão. Não passa de invenção. Um deparar com o caos, visto que o pensar não para de proliferar, misturar, alterar. É um movimento criativo de se aprender como algo se afirma, tornando-se possivel dizer sobre ele em ato, numa perspectiva percebida por quem experimenta a obra como potência criativa. O fora lançando sua força, potência para ler e decifrar signos. É na dimensão do sensivel que os signos nos impelem para uma nova tradução, pela vida eterna do pensamento, que pode calar, ecoar... O lado de dentro é coextensivo ao lado de fora, bem como a memória se estende ao esquecimento.

Uma perspectiva analítica de experimentação do pensamento na imanência do encontro,

Pois entre duas esferas absolutamente diferentes tais como entre sujeito e objeto não vigora nenhuma causalidade, nenhuma exatidão, nenhuma expressão, mas, 
acima de tudo, uma relação estética, digo, uma transposição sugestiva, uma tradução balbuciante para uma língua totalmente estranha. Algo que requer, de qualquer modo, uma esfera intermediária manifestamente poética e inventiva, bem como uma força mediadora (NIETZSCHE, 2008, p. 42, grifo do autor).

O acontecimento nas obras escolhidas para serem codificadas foi produzido na relação potente que elas têm de afetar e serem afetadas. Portanto, ao apresentar acontecimentos nas autoras negras e nordestinas, estamos a manifestar esses acontecimentos em nós na leitura de suas obras. Aqui não temos a intenção de interpretar a essência das obras ou das autoras, posto que a interpretação fala mais de quem interpreta. O acontecimento repetido, como nos fala Zizek, é sempre novo. O próprio Deleuze nos licencia para recriar as suas obras, seus conceitos e filosofia pela teoria dos sentidos, o desejo e o acolhimento como contraefetuação do acontecimento. É o poder da vontade que dará significado ao sentido, sentido às traduções e valor ao que foi valorado, liberando uma filosofia da repetição, dando nova potência ao ato e às palavras, ao pensamento e à vida. Quanto a isso,

Em Diferença e Repetição, Deleuze afirma que Nietzsche pensa a repetição da seguinte forma: 1. a repetição enquanto tal é algo novo; a novidade não surge fora, mas na própria repetição; ela é vontade, liberdade, novidade; 2. a repetição está associada ao movimento e oposta à natureza; ela não é lei natural; 3. a repetição se opõe à Lei Moral; ela é um pensamento para além do bem e do mal; não está associada a um imperativo categórico (a pretensão de legislar sobre toda e qualquer repetição) como em Kant, mas a fazer da própria repetição uma lei que reúna o singular e o universal para além da moral e assim acabe com toda lei geral e com a submissão do particular a qualquer lei geral; 4. a repetição é oposta às generalidades do hábito (habitus) e às particularidades da memória (reminiscência); a repetição é a potência positiva do esquecimento (GROPPA; REGO, 2014, posição 1.066).

A força mencionada ganha em Deleuze uma distinção, que nos convoca a pensar o problema que essa questão provoca. Uma delas seriam os agenciamentos que são as produtoras, e não o indivíduo. De modo ressonante, a potência surge das associações e heterogeneidades, das composições que lhe permitem pensar, falar, escrever. São as multiplicidades presentes nos estados de coisas, nos estilos da enunciação, nos territórios e nas desterritorializações e reterritorialidades. Esses agenciamentos ocorrem num plano de imanência, que é o real em movimento de atualização, potência completa, em ato, nela só há devires, conjunção de fluxos, sempre em processo. Esse encontro com signos é ato de sensibilidade, produzido pelo pensar - uma imagem amoral do pensamento. Ela abre o mundo, mas não o controla, representando-o ou contemplando-o; tem a ver com sentidos, não com verdades, promovendo recriações, repetições e diferenças incessantes, uma explosão de sentidos. Essas multiplicidades nos remetem à ausência de hierarquia; elas pulsam, não há sujeito e objeto, mas dimensões, conexões, composições, transbordamentos, sem princípios nem fundações, o rizoma como imagem do pensamento, criação sem fim, expansão da heterogeneidade. Uma literatura menor, que fala uma lingua de si mesma como estrangeiro, nômade, político, pois em movimento de resistência e fuga, as suas enunciações são coletivas, múltiplas. O menor sobre o maior como possibilidade infinita (GROPPA; REGO, 2014). 
Portanto, o acontecimento a ser pensado sobre o acontecimento nas obras escolhidas é um dinamismo criador, como produção de eventos, uma ontologia do presente no sentido foucaulteano. Uma diagramatização em fuga, como singularidades e não como universais, conjugações de processos sobre planos de pensamento, em ato, processo inacabado do vivido e do vivivel. O plano de imanência presente nessa obra do pensamento dá aos acontecimentos virtuais uma realidade. Como a vidência do artista, essa literatura provoca a enxergar essa realidade mesmo no seu nível menos desejável, o mais intolerável, insuportável, engendrando um pensar diferente, que interrompe a previsibilidade numa atualização inesperada, intempestiva - o acontecimento.

O livro de contos da escritora Conceição Evaristo, Insubmissas lágrimas de mulheres (2016a), que versa sobre histórias de mulheres em situação de violência doméstica ou de vulnerabilidade, o livro Poemas da recordação e outros movimentos (2017) ou ainda Olhos d'água (2016b), da mesma autora, são produções literárias que, por si mesmas, já são acontecimentos, visto que são provocadoras de muitos perceptos e intensos e diversificados afetos. Agenciamentos em composições criando imagens amorais do pensamento, pois têm compromisso com os sentidos, não com a verdade "verdadeira". A linguagem literária se quebra, se desdobra, como passagem para o fora, liberando o pensamento de toda subjetividade. Esse movimento que rompe a vontade de verdade eclode em potência a escritura de obras em acontecimento.

A abertura do livro de poemas já traz em si a ideia desse acontecimento:

O olho do sol batia sobre as roupas estendidas no varal e mamãe sorria feliz. Gotículas de água aspergindo a minha vida-menina balançavam ao vento. $\mathrm{Pe}$ quenas lágrimas dos lençóis. Pedrinhas azuis, pedaços de anil, fiapos de nuvens solitárias caídas do céu eram encontradas ao redor das bacias e tinas das lavagens de roupa. Tudo me causava uma comoção maior. A poesia me visitava e eu nem sabia... (EVARISTO, 2017, p. 9).

O eu lírico, nesse caso, ao recordar ações cotidianas de sua infância, percebe como era imensamente afetada pelas suas percepções. Mais tarde, viria a se dar conta de que a poesia corria desenfreada por suas veias, e os desdobramentos, nesse caso, são infinitos, já que o ato de produzir literatura, especialmente poesia, provoca devires ad infinitum. O plano de imanência atualizando o real num movimento sempre em devir faz emergir na superficie a linguagem que fala, e não a autora, numa performática literária como dobra desenvolvida a partir de si mesma.

O teor dos poemas que fazem parte dessa obra, Poemas da recordação e outros movimentos, como o próprio título sugere, são textos que versam sobre recordações as mais diversas do eu lírico, travestido ora de menina, ora de mulher, ora de negra; outrora, o eu lírico são outras mulheres, em outros tempos, em relação com outras realidades (são carolinas, clarices, macabeias...). A literatura menor apresenta-se com seu caráter múltiplo, coletivizado, uma nuance de um certo estrangeirismo ao falar de si em sua língua, sua cultura. E também são inúmeros os sofrimentos, as angústias, os desejos - situações-chave para o desencadear de acontecimentos, como no poema "Ao escrever...". A autora inicia o poema demonstrando a angústia do eu lírico que escreve sensações cruas, como a fome - "Ao escrever a fome/com as palmas das mãos vazias/quando o buraco-estômago/expele famélicos desejos/há neste demente movimento/o sonho-esperança/de alguma migalha alimento" (1-7) (EVARISTO, 2017, p. 90 ). 
Na linguagem literária, o acontecimento se dá no rompimento, as verdades são abaladas, o fixo se dilui, ultrapassando as oposições entre o pessoal e o impessoal, subjetividade e objetividade, interioridade e exterioridade, pois o fora é o lugar do encontro de forças, o interior também vem dançar na superfície, o espaço de relação entre o real e o virtual - plano de imanência. Os perceptos e afetos são os acontecimentos criados pela literatura. Contudo, eles são exteriores à linguagem. Mas o exterior da linguagem, com Deleuze, não é exterior à linguagem, ele é o exterior da linguagem. Não existe fora dela, antes é o seu fora, a sua ponta extrema, laminar. O atual é objetividade enquanto o virtual é subjetivo. Real e atual não são a mesma coisa para Deleuze.

O virtual não se opõe ao real, mas só ao atual. O virtual possui realidade plena enquanto virtual. [...] O virtual deve ser definido, então, como uma parte estrita do objeto real - como sim o objeto tivesse uma de suas partes no virtual [...]. [...] longe de ser indeterminado, o virtual está absolutamente determinado. [...] o virtual, pelo contrário, é característico da Ideia; é a partir da sua realidade que a existência se produz, e é produzida formalmente (DELEUZE; GUATTARI, 2006, p. 338-342).

Mais adiante, no mesmo poema, o eu lírico derrama a dor de sua solidão: "Ao escrever a dor,/sozinha,/buscando a ressonância/do outro em mim/há neste constante movimento/a ilusão-esperança/da dupla sonância nossa" (15-21) (EVARISTO, 2017, p. 90-91). Fome, frio, dor e outras angústias aparecem neste e em outros poemas da autora, tratando-se de sentimentos que provocam mudanças profundas no eu lírico, guardadas na memória e influenciando a sua escrita, que por sua vez provoca outras pessoas, através do processo de recepção.

As lágrimas insubmissas das mulheres narradas nos contos de Evaristo (2016a) são causadas por traumas diversos: umas são derramadas por causa de violência cometida pelo marido, namorado ou companheiro; outras por conta da lembrança recorrente do trauma de infância por ter assistido ao parto da mãe, ao parir uma criança prematura (o irmãozinho caçula da personagem). Tudo isso é acontecimento, que tem desdobramentos que se desdobram.

Um rizoma que bifurca linhas diversas, linhas de fuga, numa heterogeneidade de imagens, trajetos, trejeitos, mundos fora dos mundos, que na diversidade vão compondo repetições de percepções e afetamentos não hierarquizados, imagens do pensamento, num movimento permanente de atualização. No livro de contos Olhos d'água, Evaristo (2016b) também traz inúmeras situações que remetem ao acontecimento deleuziano: são mortes, situações de violência, estupros, assassinatos - episódios traumáticos de vidas de personagens que ficariam marcados e deixariam a marca também em outros, como ressonância da própria marca. Marcas em movimento de imanência, o real em atualização permanente. O eterno retorno. Eterno devir.

No conto "O cooper de Cida", o acontecimento pode ser identificado a partir de um estalo da personagem que, numa manhã ordinária de terça-feira, passa a enxergar o mundo de um novo prisma, passando a perceber coisas e necessidades das quais nunca tinha se dado conta, até aquele momento:

Todas as manhãs, os pés de Cida pisavam rápido o calçadão da praia, iam e vinham em toques rápidos e furtivos, como se tivessem envergonhados dos carinhos que o solo pudesse lhes insinuar no decorrer da marcha. A moça imprimia mais e mais velocidade a sua louca e solitária maratona. Corria contra ela 
própria, não perdendo e não ganhando nunca. Mas, naquele dia, a semidesperta manhã inundava Cida de um sentimento pachorrento, de um desejo de querer parar, de não querer ir. Sem perceber, permitiu uma lentidão a seus passos, e pela primeira vez viu o mar. [...]. Hoje ela não iria trabalhar, queria parar um pouco, não fazer nada de nada talvez. E só então falou significativamente uma expressão que tanto usara e escutara. Mas falou tão baixinho, como se fosse um momento único de uma misteriosa e profunda prece. Ela ia dar um tempo para ela (EVARISTO, 2016b, p. 69-70).

Nesse conto específico, o acontecimento é dado por algo ordinário, mas a personagem é que tem seu olhar modificado pela realidade que, para Zizek (2017, p. 16) "[...] ela é um acontecimento: em sua forma mais elementar, um acontecimento não é algo que ocorra dentro do mundo, mas uma mudança no próprio arcabouço pelo qual percebemos o mundo e nos envolvemos nele". Assim, o insight de Cida fez com que ela modificasse o seu modo de perceber a si e ao mundo, alterando, por outro lado, sua maneira de agir, tanto em relação a si mesma quanto ao trabalho, afetando também outras pessoas com seus atos, provocados por sua nova forma de enxergar.

A literatura menor exige essa desterritorialização, arrancar-se fora do seu lugar, fora de si, um exílio, para uma reterritorialidade. O fora e o dentro em (des)encontros e (des)dobramentos imanentes, emergindo na superficie e dobrando-se sobre si mesma, curvando a força em subjetivação. O que não diz de caráter de unidade, universalidade, interioridade, identidade, pessoalidade. Situação semelhante à de Cida ocorre no conto clariciano "Amor", do livro Laços de família, analisado por Cícero Bezerra (2017) em artigo no qual relaciona acontecimento, Deus e literatura em Clarice Lispector. A personagem Ana, assim como Cida, está andando na rua e tem um estalo, a partir de algo que serve como gatilho para o acontecimento. A esse respeito, esclarece Bezerra (2017, p. 1512):

É importante perceber que não se trata de um confronto entre Ana e o cego. Este último permanece passivo, exceto no ato de mascar chicles. É Ana que vê no "outro", que sequer lhe enxerga, os elementos necessários para a instauração de uma crise. Crise compreendida, como dissemos antes, como ruptura, transgressão de um suposto estado de segurança. Diríamos que o cego é uma porta aberta para a escuridão profunda da vida que Ana, em sua organização, tenta dublar, mas semelhante a G. H., perde a muleta que lhe dava sustentação. $O$ aparecimento do cego no conto, abre para uma nova experiência vivida pela protagonista que redefine os trilhos textuais da narrativa.

Já a poeta Livia Natália traz em sua poesia a mulher, a negra, a filha de santo e todas as delícias e dores que vêm junto no pacote dessas identidades marcadas por traumas, preconceitos, luta, superação e resistência: a figura da mulher que sangra é recorrente em seus poemas; a presença-ausência da morte também aparece bastante em suas páginas; o transcendental, o místico amparado pelo culto aos orixás marca presença em sua poesia.

Os titulos das obras mais conhecidas da escritora, de antemão, já remetem a um devir, um fluir - são nomes de obras do ciclo das águas: Água negra e outras águas (2016), Correntezas e outros estudos marinhos (2015), Dia bonito pra chover (2017) e Sobejos do mar (2017). As águas sugerem movimento, transformação, mudança constante e, portanto, apontam para o acontecimento. 
Livia Natália é uma poeta baiana contemporânea, que traz em seus poemas traduções inquietantes do que é humano. Autora de vários livros publicados, entre eles Água negra e outras águas, de 2016, reimpresso em 2017, do qual faz parte o poema "Visitação", em que nos debruçamos para tratar da morte enquanto acontecimento. Evidentemente, há diversas interpretações de suas produções, a partir de outras demarcações, seja pelo viés de raça, classe, religiosidade ou gênero.

"Visitação" compõe a seção do livro intitulada "Desaguar", referindo-se simbolicamente à morte do corpo e, ao mesmo tempo, indicando uma transcendência da alma que, segundo o título da seção, deságua em outro lugar, que pode ser em outras águas. O fato é que a palavra desaguar sugere um fim e um começo, como os rios que deságuam no mar - a ideia ofertada por essa visão é de uma cosmovisão sublime, em que são explorados o inescrutável e o inexprimível exemplificados na grandiosidade da morte e na impossibilidade de exprimir o que vem depois dela.

Um estado de devir permanente, imanência como abertura para o trânsito entre o fora e o dentro, o real e o virtual, em constante atualização, dobrando a força e criando uma ética e uma estética de viver, que nada têm a ver com moralidade. Mas um construir-se na errância, constituindo novas formas de existência.

"Visitação", assim como os outros poemas da referida seção, tratam da morte. Eis como se inicia: "Morreu o criador de passarinhos. //Sei disso não pela ausência obtusa sentada na sua cadeira, /à porta da casa. /Ele morreu porque nem as gaiolas sobraram / no vazio defunto da varanda envidraçada". Nesse poema, a morte de um criador de passarinhos é poetizada na linguagem da poeta, que recorre à temática em diversos poemas deste e de outros livros: é o filho que não chegou a nascer; a mãe que vive como se já tivesse morrido; o morrer poético em cada poesia traduz o luto presente na voz poética da escritora.

Para Zizek (2017, p. 8), "Existe num acontecimento, por definição, algo de milagroso, dos milagres de nossa vida cotidiana até aqueles das esferas mais sublimes, incluindo a do divino". Em "Visitação", a presença do elemento transcendental é pungente - as imagens que poderiam ser as mais tristes são sublimadas com expressões transcendentais: "Morreu o criador de passarinhos. // (Hora destas planam no desassossego do céu, /soltas, /as miudezas de vida.) //Seu corpo se abriga na sepultura calma". Nesses versos, há a presença do acontecimento, explícita na palavra "céu", que remete à ideia de imortalidade da alma, da possibilidade de uma outra vida após a morte do corpo, o que é reforçado pelo próximo verso, no qual o eu lírico afirma que o corpo do criador de passarinhos está abrigado na "sepultura calma".

O emprego de palavras como defunto e sepultura, por exemplo, aproxima o texto da morbidez romântica, típica do Byronismo - revelando o lado grotesco explorado pela poeta; e a recorrência da morte como tema reitera essa tendência de aliar sublime e grotesco, reforçando-a. Livia Natália recorre à temática da morte em toda a seção "Desaguar" e também em outras obras.

As duas estrofes finais de "Visitação" trazem um questionamento e uma ironia, pelos quais o eu lírico se afasta da melancolia e reflete sobre as possíveis consequências da morte de alguém que morre tendo sido, em vida, um criador de passarinhos, ou seja, uma pessoa que mantinha pássaros cativos, engaiolados. A seguir, a transcrição do questionamento: "Mas que é feito da alma /que daqui vislumbro / num voo cego, / de asas cortadas?". A pergunta deixa entrever 
a preocupação do eu lírico com o destino da alma do criador de passarinhos para esse lugar desconhecido (voo cego), sem o aparato necessário (asas cortadas). A um só tempo, há mostras de reflexividade e imagens transcendentes que nos remetem ao sublime cultivado pelos românticos, evidenciando novamente o caráter de acontecimento, já que há repercussão a partir da morte do criador de passarinhos.

A poeta, no decorrer do poema, ora trata do corpo que morreu, ora reporta à alma, como na penúltima estrofe. A religiosidade está presente no poema objeto da presente análise e também em vários outros da poeta Lívia Natália, embora, na maioria deles, a religiosidade explorada seja a de matriz africana - o candomblé -, mas percebem-se elementos do sincretismo religioso tão presente na Bahia, como o que ocorre no poema "Visitação". Nesse caso, "Acontecimento designa uma nova revelação esporádica do ser, a emergência de um novo mundo (um horizonte de significado no interior do qual todas as entidades aparecem)" (ZIZEK, 2017, p. 34). Experiência com o encantamento, agenciando multiplicidades, produzindo conexões e devires não hierarquizados.

A estrofe final, "Há no céu, /decerto, /uma gaiola dourada", encerra uma ironia que, ao modo romântico, revisa os sentidos explorados no decorrer do poema, até então, dando a entender que o encarcerador de outrora será o encarcerado de agora, ficando, apesar de estar no céu, preso a uma "gaiola dourada". Essa estrofe tanto reflete o sublime, no fato da elevação ao alto, a uma esfera superior (no caso, o céu), quanto é irônica, uma vez que carrega o sentido conotativo do provável prisioneiro que costumava aprisionar. A ironia consiste justamente no fato de que se espera que a alma, livre do corpo de carne, alcance paz e liberdade, o que não ocorre em "Visitação", já que uma "gaiola dourada" parece estar à espera da alma do criador de passarinhos - eis um dos desdobramentos tanto da morte quanto das ações pregressas do eu lírico. Embora transite por uma pretensa sentença, a alma livre do corpo do criador de passarinho não está num pensamento dado, mas fulgura na incerteza, vez que a imagem literária é de além morte. Vida além da morte, plano de imanência que ao mesmo tempo turva essa imagem anunciada de um pensamento em sentido, não à verdade, mas a uma cosmovisão errante - uma imagem pensamento também amoral. No entanto, o inatingivel se reverbera de um atingimento possível pela obra literária.

Há nesse poema de Lívia Natália indícios de acontecimento, materializados na figura da morte, da perda; mas aparecem também o sublime e o grotesco, a ironia e uma certa flexibilização de gêneros, já que o poema "Visitação" não possui estrofes regulares, a métrica também é totalmente irregular; não há rimas, nem sonoridade - o ritmo mais lento, mais pachorrento, evidenciado pela disposição das estrofes e dos versos e pelos sinais de pontuação (pontos-e-vírgulas, em geral; nenhuma exclamação), tudo isso o aproxima bastante da prosa, o que nos remete à desconstrução, a uma quebra de linearidade, do esperado.

Como em Kafka, essa literatura é uma anunciação coletiva. Um povo menor produzindo pensamentos como atos revolucionários. Deleuze afirma que a literatura tem a ver com o povo, embrenhada de impessoalidade na qual a individualidade não se assenta. Não seguir padrões é altruísmo, é processo de coletividade. Uma produção rizomática, não hierarquizada, entremeada de repetições deleuzianas, produzindo a diferença (DELEUZE; GUATTARI, 2003).

A respeito da intersecção de gêneros, Victor Hugo (2007, p. 8) vê como um dos postulados românticos quando afirma que 
Os princípios de mistura dos gêneros, de rejeição das regras, de recusa da imitação dos modelos, de liberdade na arte, estimularam e estimulariam, no futuro, a imaginação de dramaturgos, abrindo novos caminhos aos jovens talentos.

Assim, pode-se supor que a poeta pode ter herdado a transgressão da revolução iniciada com os românticos e que seria, mais tarde, reiterada e aprimorada pelos modernistas - tal transgressão perpassou gerações e está muito presente nas composições mais atuais, como é o caso da poesia de Livia Natália.

Embora singular, ela produz um acontecimento, pois livre dos acintes da subjetividade e da objetividade, o real entra num estado em que já não há limites; essa dança no fora permite uma plenitude anônima, uma distinção que faz não se reconhecer mais. A literatura anunciando a passagem libertadora do eu, do ego, para o ele, o nós, a coletividade, constituindo-se singularidade. Repetição e diferença.

"Visitação" é um poema composto de oito estrofes, sendo que uma delas, "Morreu o criador de passarinhos", se repete, como se fosse um refrão - a coisa mais tradicional na forma de sua poesia, pois todo o restante destoa da poesia formal clássica, aderindo a uma dissonância moderna, visto que há estrofes com um verso, com quatro versos e com três versos, todos irregulares. Nesse sentido, a autora pode ser considerada adepta de novos modelos estéticos, dissonante em relação aos modelos clássicos, em claro conflito com as convenções.

Um movimento de imanência no qual o real se atualiza criando o singular. É na impessoalidade que se dá vez à errância, aos devires, à potência que circula no fora, para uma composição múltipla.

A narratividade poética também se deixa entrever no emprego de verbos: é como se o eu lírico estivesse contando sobre a morte de alguém conhecido: talvez um vizinho que costumava criar pássaros presos em gaiolas. A poeta emprega metáforas abertas, que são típicas da arte romântica, uma das formas de demonstrar a experiência sem fechar a obra, deixando-a em aberto, através de sugestões (o caso da "gaiola dourada", por exemplo) e de plasticidade (a forma ou a falta dela, a aproximação com a narrativa) que criam as analogias necessárias para interpretações das metáforas presentes no poema.

O poema "Visitação" faz parte da seção "Desaguar", como foi explicitado anteriormente, a qual abriga também os poemas "Os barcos", "Enterrado vivo", "Elegia" (a um jovem morto pela polícia em Salvador), "A uma ausente" e "Oriki para Osun" - todos tratando, direta ou indiretamente, da temática da morte.

Assim como a morte, a negação está presente na forma literária. Esse tudo ou nada se dá como acontecimento na literatura, a sua palavra encontra o não ser do mundo se realizando nessa própria falta como possibilidade; paradoxalmente, a linguagem literária faz desaparecer as coisas do mundo revelando a presença desse desaparecimento.

É importante ressaltar que os títulos dos livros de Livia Natália carregam um mar de simbologia presente no elemento água explorado pela autora, já que, de alguma forma, remetem ao universo líquido, aquático: Água negra e outras águas (2016), Correntezas e outros estudos marinhos (2015) e Sobejos do mar (2017) são exemplos de obras em que a temática das águas é exaustivamente explorada, inclusive no interior das obras, em que tanto títulos quanto temas de poemas giram em torno do mesmo assunto, via de regra. $\mathrm{O}$ acontecimento também consta na inspiração do móvel, errante, flexível, fluido, como uma imagem 
pensamento amoral, posto que possa atravessar fronteiras sem nelas se fixar, deslizando como as águas sobre o constituindo, desviando, escavando, criando rasgos, fazendo curvas, inventando novos rumos, novos mundos.

Sávio Freitas (2015, p. 111), em uma análise do livro Água negra e outras águas, sintetiza a presença da água nessa produção de Livia Natália:

Trazendo poeticamente um fluxo de águas comandadas e abençoadas por Osun e todo panteão Yorubá, Lívia Natália faz de sua poesia mar, rio, correntezas e marés que permitem o tráfego de discussões políticas que enfatizam as relações de raça, classe e gênero por [meio] de problematizações de temas como: crenças de matriz africana, maternidade, casamento, traição, políticas de afirmação, memória oral, afrodescendência, aborto, entre tantas outras correntezas.

Está claro que a interpretação de Freitas (2015) tem um viés diverso daquele a que nos propomos e que, diga-se de passagem, não tem a menor intenção de ser conclusiva ou fechada, apenas mais uma possibilidade de análise, dentre tantas outras. Nesse sentido, levando-se em consideração a observação de Freitas sobre a referida obra e pensando na linha aqui desenvolvida, é possivel afirmar que a obra da autora, mesmo de modo velado, apresenta um viés de acontecimento, implícito nos títulos aquáticos, que podem simbolizar a grandiosidade da natureza em contraste com a pequenez humana; ou a transitoriedade da vida (rios correntes, ondas que vêm e vão etc.); ou ainda o fluxo contínuo das ações humanas que se perdem nas correntezas das águas e ressurgem ou deságuam em outras águas, a um só tempo.

Jarid Arraes (2016), com o livro As lendas de Dandara, inventa outra realidade, na qual a presença da heroína negra é possivel, já que há relatos esparsos sobre a suposta companheira de Zumbi dos Palmares, mas não há registros ou testemunhas que possam dar conta da existência material de Dandara. Assim, a escritora se assenhora da caneta e cria a personagem, possibilitando a sua existência de outra forma, tornando o impossivel possivel e reiterando o caráter acontecimental da literatura.

Distanciando-se da certeza, a literatura ensimesmada transforma a linguagem criando sua própria realidade.

\section{CONCluINDO: É PRECISO TERMINAR PARA COMEÇAR A ACONTECER}

Evidentemente, há inúmeras outras obras de escritoras, tanto negras quanto nordestinas, que trazem exemplos de acontecimentos em suas páginas. Isso pode ser trabalho para outro momento. O exposto neste artigo teve a pretensão de evidenciar como essas autoras têm facilidade em desenvolver o jogo da escritura, através de um trabalho minucioso com a linguagem, trazendo à tona vários acontecimentos que movimentam os textos, apontando para possiveis desdobramentos.

Os acontecimentos, via de regra, exprimem um fim de ciclo de mesmice, passividade ou normalidade que dá lugar a uma sucessão de eventos interligados e imbricados numa trama de causa-consequências que causam outras coisas e assim sucessivamente, sem cessar. Um trauma, uma violência, um insight, a morte - fatos que marcam o fim de alguma coisa e o desencadear de uma série de outras coisas, derivadas da primeira e provocadoras de novas coisas, que estão sempre vindo a ser, nunca sendo. 
A literatura é o lugar do acontecimento por excelência, uma vez que é provocadora de perceptos e afetos que podem modificar os leitores. Embora não tenha a intenção de mudar o mundo, ela transita na imanência, pois as coisas não são, ainda; tudo está por acontecer. É uma oposição ao transcendente, mas não ao transcendental. Esse último opera num puro plano de imanência, que escapa a todo instante da condição de sujeito e do que seria consciência. Uma subjetividade construída e aberta para a experiência do acontecimento. Ademais, a leitura literária permite a construção de outros mundos, de outras realidades, diferentes do que está posto. Não como a realização do possível, mas saindo dela para se dar com outros mundos, outros sentidos e agrupamentos virtuais. Além disso, ler literatura permite a evasão dessa realidade fragmentada, individualista e capitalista, através das linhas de fuga oportunizadas pelos textos literários, que permitem a criação de outras formas de viver.

Nesse sentido, existir é em si resistir. Uma ética e estética do descompromisso com o constituído, o moldado. Essa questão nos diz da subjetivação, dobra da força, pregas, produzindo um dentro do fora constituindo uma realidade virtual, um "espaço" habitável dentro do ciclone; nele se pode viver essa vitalidade, vontade de potência, o interior do exterior criando incessantemente novas formas de existência. A instauração de um sempre outro. Novas subjetivações que nos colocam diante do mundo, um plano imanente apenas a si mesmo.

Essa confluência entre ciência, filosofia e arte, cujos agenciamentos rizomáticos dessa análise que se quer experimentação da obra-imagens, num plano de imanência, cuja força do pensamento ético-estético e político situa o método de conhecer como acontecimento.

\section{EVENTS IN BLACK AND/OR NORTHEASTERN AUTHORS}

Abstract: We discussed the notion of an event (Deleuze) in works by black and / or northeastern writers, aiming to highlight perceptions and affections, considering becoming and deconstruction. We analyzed literary works by Conceição Evaristo, Livia Natália and Jarid Arraes. To this end, we moved authors such as Deleuze and Guattari, Zizek, Nietzsche and others who dialogue with our proposal. Thus, the works refer to the possibilities of literature as an event, which is constantly changing.

Keywords: Literature. Event. Black writers. Brazilian Northeastern writers. Deleuze.

\section{REFERÊNCIAS}

ARRAES, J. As lendas de Dandara. São Paulo: Editora de Cultura, 2016.

BEZERRA, C. C. Clarice Lispector: acontecimento, Deus e literatura. Horizonte, Belo Horizonte, v. 15, n. 48, p. 1504-1524, out./dez. 2017.

CANDIDO, A. O direito à literatura. In: CANDIDO, A. Vários escritos. São Paulo: Duas Cidades, 1995.

DELEUZE, G.; GUATTARI, F. Diferença e repetição. Tradução Luiz Orlandi e Roberto Machado. 3. ed. Rio de Janeiro: Graal, 2006. 
DELEUZE, G.; GUATTARI, F. Kafka: para uma literatura menor. Lisboa: Assírio \& Alvim, 2003.

DELEUZE, G.; GUATTARI, F. Mil platôs: capitalismo e esquizofrenia. São Paulo: Editora 34, 2013.

EVARISTO, C. Insubmissas lágrimas de mulheres. 2. ed. Rio de Janeiro: Malê, 2016 .

EVARISTO, C. Olhos d'água. Rio de Janeiro: Pallas: Fundação Biblioteca Nacional, 2016b.

EVARISTO, C. Poemas da recordação e outros movimentos. Rio de Janeiro: Malê, 2017.

FREITAS, S. R. F. de. O caminho das águas na poesia de Livia Natália. Identidade!, São Leopoldo, v. 20, n. 2, p. 103-111, jul./dez. 2015. Disponivel em: http:// periodicos.est.edu.br/identidade. Acesso em: 22 maio 2018.

GROPPA, J. A.; REGO, T. C. (org.). Deleuze pensa a educação. São Paulo: Editora Segmento, 2014. E-book. (Coleção Biblioteca do Professor).

HUGO, V. Do grotesco e do sublime. Tradução e notas Célia Berrettini. São Paulo: Perspectiva, 2007.

LEVY, T. S. A experiência do fora: Blanchot, Foucault e Deleuze. Rio de Janeiro: Civilização Brasileira, 2011.

NATÁLIA, L. Água negra e outras águas. Organização e ilustração Fernando Oberlaender. 2. ed. Salvador: EPP, 2016.

NATÁlIA, L. Correntezas e outros estudos marinhos. Ilustração João David Araújo Zilhão. Salvador: Editora Ogum's Toques Negros, 2015.

NATÁLIA, L. Sobejos do mar. Coordenação e ilustração Fernando Oberlaender. Salvador: EPP, 2017.

NIETZSCHE, F. Sobre verdade mentira. São Paulo: Hedra, 2008.

ROJAS, A. S.; SERRANO, J. F. M.; SILVA, M. A. P. Filosofia y literatura em Deleuze y Guattari: creación y acontecimento. Práxis Filosófica Nueva Serie, n. 45, p. 171-202, jul./dic. 2017.

ROSA, J. G. Grande sertão: veredas. Rio de Janeiro: Editora Nova Aguilar, 1994. (Biblioteca Luso-brasileira, v. 2).

ZIZEK, S. Acontecimento: uma viagem filosófica através de um conceito. Tradução Carlos Alberto Medeiros. Rio de Janeiro: Zahar, 2017.

ZOURABICHVILI, F. Deleuze: uma filosofia do acontecimento. Tradução Luiz B. L. Orlandi. São Paulo: Editora 34, 2016. 